\title{
The Level of Satisfaction of the General Public with Health Care Provided by Their General Practitioner
}

\author{
I. Gulasova (Ivica Gulasova)', J. Breza, jr. (Jan Breza, jr.)², J. Breza (J. Breza)³, \\ L. Gornerova (Lenka Gornerova) ${ }^{4}$
}

${ }^{1}$ St. Elizabeth University of Health \& Social Sciences, Bratislava, Slovakia

Original Article

${ }^{2}$ Department of Urology and Radiology and Center for kidney transplantations, Kramare University Hospital, Bratislava, Slovakia

${ }^{3}$ Department of Urology and Radiology and Center for kidney transplantations, Kramare University Hospital, Bratislava, Slovakia, Medical Faculty of University of Komensky, Bratislava, Slovakia

${ }^{4}$ College of Polytechnics, Jihlava, Czech Republic

\section{E-mail address:}

ivica.gulasova4@gmail.com

\section{Reprint address:}

Ivica Gulasova

St. Elizabeth University of Health \& Social Sciences, Bratislava

Nam. 1. Maja 1

81000 Bratislava

Slovakia

Source: Clinical Social Work and Health Intervention

Pages: $36-43$

Volume: 9

Cited references: 1

Issue: 4

\section{Reviewers:}

Gunther Dorfmeister

Vienna General Hospital, Vienna, Austria

Jirina Kafkova

Nairobi, St. Bakitha Clinic, Kenya

\section{Key words:}

Satisfaction, General Practitioner, Communication, Expertise, Health Status.

\section{Publisher:}

International Society of Applied Preventive Medicine i-gap

CSWHI 2018; 9(4): 36 - 43; DOI 10.22359/cswhi_9_4_06 ( 2018 Clinical Social Work and Health Intervention 


\section{Abstract:}

In this article authors describe research aimed to determine the level of satisfaction of the lay public with health care provided by outpatient practitioners. The authors have set one main objective and five sub-objectives and 5 working hypotheses. A basic set of respondents were 300 randomly approached Slovak citizens. This article analyses the results of this survey - its findings. In the end of the article are proposed several recommendations for practice.

\section{Introduction}

Primary health care is the coordinated and complex health and social care provided by health workers at the first contact of people with health systems based on a longterm continuous approach to the individual. It is a set of activities related to health promotion, prevention, examination, treatment, rehabilitation and nursing care. These activities are provided as close to the patient's own environment as possible and respect his bio-psycho-social needs. The key medical discipline of primary care is universal (practical) medicine.

Characteristics of care in general (clinical) medicine:

- Universality: solves unsorted health problems of the population, regardless of age, gender or other characteristics of the person concerned; must be easily accessible with minimum delay.

- Continuity: focuses more on the person than on the disease based on a long-term relationship between patient and doctor.

- Comprehensively: provides integrated care in health promotion, disease prevention, rehabilitation and treatment.

- Coordination: informing patients about appropriate health care; the manner of its optimal use providing patient's consultation with a specialist.

- Cooperation: General Practitioners work with other health and social care providers.
- Family Orientation: addresses the incidence of disease in the family (hereditary dispositions).

- Community Orientation: addresses the health problems of the population living in the community; cooperation with other professionals from fields other than Health (Hanzlíková et al. 2004).

Primary health care must be organized so that it is accessible by each citizen. It must be based on the density and size of the physician's network perimeter. Size of physician's circumference (rather number of clients) should be set so that the 8-hour ambulance doctor could provide the care to his patients. The ideal circuit should have 1,500 patients with tolerance, given the geographic and demographic conditions in 1,800 patients aged 18 years.

The role of primary care physicians is:

- Basic early diagnosis of diseases.

- Monitoring and follow-up of major chronic diseases, especially in patients with advanced diseases of civilization.

- Prevention implemented in the form of preventive examinations including vaccinations.

\section{Objectives of the survey}

Main objective: To determine the level of satisfaction among the general public 
with the overall healthcare provided by General Practitioner.

\section{Sub-objectives:}

1. Find satisfaction with the availability of primary health care to citizens.

2. Find satisfaction with the provision of information by health professionals.

3. Find satisfaction with approach of Doctors and Nurses to patients.

4. Obtain an overview of the citizens' awareness of preventive examinations and vaccinations.

5. Identify citizens' views on treatment and outpatient facilities.

\section{Working hypotheses}

H1 We assume that for respondents, in evaluation of satisfaction of care by their GP not only medical expertise but also approaches by Doctors and Nurses to patients and communication

with them is important.

H2 We assume that respondents will not be satisfied with providing of information about their state of health, examinations and treatment.

H3 We assume that respondents will have enough information about the possibilities of preventive examinations and vaccinations, from GP and also from other sources, and that they follow preventive examinations.

H4 We expect that the majority of respondents would not change their GP because they are in his care for a long time and are satisfied with his care, availability and tactful approach.

H5 We assume that for the satisfaction rating, clean and neat environments of ambulance and waiting areas as well as equipment are very important.

\section{Characteristic of respondent sample}

Number of respondents: 300 - men and women in the age group 20 to 80 years. Respondents were randomly asked to complete the questionnaire.

\section{Research methods}

As the principal research method was a questionnaire of our own design where we asked for subjective personal opinions of the respondents. This questionnaire survey was anonymous.

The following areas were covered in the questionnaire we used:

- Introduction of a questionnaire containing demographic data.

- Closed questions where respondents selected answers from the submitted alternatives.

- Semi-open questions were offered closed answers to which it was possible to add open-ended comments.

- Our respondents did not use open response options, they used only offered alternatives.

\section{Analysis of demographic data}

Overview of age in three age groups and gender of respondents are presented in the following table.

\begin{tabular}{|l|l|l|l|}
\hline Age group & Men/n & Women/n & $\%$ \\
\hline $20-40$ years & 20 & 40 & $20 \%$ \\
\hline $40-60$ years & 80 & 70 & $50 \%$ \\
\hline $60-80$ years & 50 & 40 & $30 \%$ \\
\hline $\mathrm{N}$ & 150 & 150 & $100 \%$ \\
\hline
\end{tabular}

\section{Analysis of the questionnaire responses}

1. How long have you been in the care of your practical (district) Doctor? 


\begin{tabular}{|l|l|l|}
\hline Years of care & $\mathrm{n}$ & $\%$ \\
\hline $0-5$ years & 60 & $20 \%$ \\
\hline $5-10$ years & 60 & $20 \%$ \\
\hline More than 10 years & 180 & $60 \%$ \\
\hline $\mathrm{N}$ & 300 & $100 \%$ \\
\hline
\end{tabular}

5. Did your Doctor provide you enough information about free preventative examinations and vaccinations which under the current legislation you have been entitled to?

2. What are your most frequent reasons for visits to your GP?

\begin{tabular}{|l|c|c|}
\hline Answers & $\mathrm{n}$ & $\%$ \\
\hline $\begin{array}{l}\text { I go when I have a medical } \\
\text { problem }\end{array}$ & 150 & $50 \%$ \\
\hline $\begin{array}{l}\text { Only in case of any acute illness } \\
\text { (viral illness) } \\
\text { that cannot handle in my own }\end{array}$ & 70 & $23 \%$ \\
\hline $\begin{array}{l}\text { If I need to prescribe medicines } \\
\text { I am taking for a long time }\end{array}$ & 60 & $20 \%$ \\
\hline $\begin{array}{l}\text { For purposes of preventive } \\
\text { examinations }\end{array}$ & 20 & $7 \%$ \\
\hline I do not visit the doctor at all & 0 & $0 \%$ \\
\hline $\mathrm{N}$ & 300 & 100 \\
\hline
\end{tabular}

3. Are you generally satisfied with the care provided by your GP?

\begin{tabular}{|l|c|c|}
\hline Answers & $\mathrm{n}$ & $\%$ \\
\hline Satisfied & 240 & $80 \%$ \\
\hline Partially satisfied & 60 & $20 \%$ \\
\hline Rather dissatisfied & 0 & 0 \\
\hline $\begin{array}{l}\text { If dissatisfied, please specify } \\
\text { why }\end{array}$ & 0 & 0 \\
\hline $\mathrm{N}$ & 300 & $100 \%$ \\
\hline
\end{tabular}

4. What do you consider as the most important when assessing satisfaction with your GP?

\begin{tabular}{|l|c|c|}
\hline Answers & 5. & $\%$ \\
\hline Expertise of doctor & 160 & $53.3 \%$ \\
\hline $\begin{array}{l}\text { Humane approach of doctor } \\
\text { to patients }\end{array}$ & 130 & $43.3 \%$ \\
\hline Age of doctor & 0 & $0 \%$ \\
\hline $\begin{array}{l}\text { Whether it's a male or female } \\
\text { doctor }\end{array}$ & 10 & $3.3 \%$ \\
\hline If other reasons please specify & 0 & 0 \\
\hline $\mathrm{N}$ & 300 & \\
\hline
\end{tabular}

7. Do you visit your medical practitioner for preventive examinations?

\begin{tabular}{|l|c|c|c|c|}
\hline Answer & $\begin{array}{c}20-40 \\
\text { years/n }\end{array}$ & $\begin{array}{c}40-60 \\
\text { years/n }\end{array}$ & $\begin{array}{c}60-80 \\
\text { years/n }\end{array}$ & $\%$ \\
\hline $\begin{array}{l}\text { Yes, re- } \\
\text { gularly }\end{array}$ & 20 & 20 & 0 & $13.3 \%$ \\
\hline $\begin{array}{l}\text { Irregu- } \\
\text { larly }\end{array}$ & 10 & 100 & 0 & $36.6 \%$ \\
\hline I do not & 30 & 30 & 90 & $50 \%$ \\
\hline $\mathrm{N}$ & 60 & 150 & 90 & $100 \%$ \\
\hline
\end{tabular}


8. Did your Doctor provide you with enough information about the necessity and content of all examinations he prescribed you?

\begin{tabular}{|l|l|l|}
\hline Answer & $\mathrm{n}$ & $\%$ \\
\hline Yes, completely & 270 & $90 \%$ \\
\hline Partially & 30 & $10 \%$ \\
\hline Insufficiently & 0 & $0 \%$ \\
\hline $\mathrm{N}$ & 300 & $100 \%$ \\
\hline
\end{tabular}

9. Do you feel that this information was presented clearly enough?

\begin{tabular}{|l|l|l|}
\hline Answer & $\mathrm{n}$ & $\%$ \\
\hline Yes, completely & 250 & $83.3 \%$ \\
\hline Only partially & 20 & $6.6 \%$ \\
\hline $\begin{array}{l}\text { No, there were too many } \\
\text { medical terms }\end{array}$ & 30 & $10 \%$ \\
\hline $\mathrm{N}$ & 300 & $100 \%$ \\
\hline
\end{tabular}

10. Did your Doctor give you the opportunity to express agreement or disagreement with the examination or treatment?

\begin{tabular}{|l|l|l|}
\hline Answer & $\mathrm{n}$ & $\%$ \\
\hline Yes & 210 & $70 \%$ \\
\hline No & 0 & $0 \%$ \\
\hline I left it on the doctor & 90 & $30 \%$ \\
\hline N & 300 & $100 \%$ \\
\hline
\end{tabular}

11. When prescribing new medications or changing medications, did the Doctor point to the possible adverse effects as well as the surcharge for the medicaments?

\begin{tabular}{|l|l|l|}
\hline Answer & $\mathrm{n}$ & $\%$ \\
\hline Yes, ever & 200 & $66.6 \%$ \\
\hline Sometimes & 100 & $33.3 \%$ \\
\hline No, never & 0 & $0 \%$ \\
\hline N & 300 & $100 \%$ \\
\hline
\end{tabular}

12. How would you evaluate approach of Nurses to patient in the office of your doctor?

\begin{tabular}{|l|l|l|}
\hline Answer & $\mathrm{n}$ & $\%$ \\
\hline Very good & 230 & $76.6 \%$ \\
\hline Good & 70 & $23.3 \%$ \\
\hline Bad & 0 & $0 \%$ \\
\hline N & 300 & $100 \%$ \\
\hline
\end{tabular}

13. Did the Nurse explain before each performance what she will do?

\begin{tabular}{|l|l|l|}
\hline Answer & $\mathrm{n}$ & $\%$ \\
\hline Yes, ever & 240 & $80 \%$ \\
\hline Sometimes & 60 & $20 \%$ \\
\hline No, never & 0 & $0 \%$ \\
\hline N & 300 & $100 \%$ \\
\hline
\end{tabular}

14. Did Nurse and Doctor respect you when you explained your problems and did they respect your privacy during examinations?

\begin{tabular}{|l|l|l|}
\hline Answer & $\mathrm{n}$ & $\%$ \\
\hline Yes, ever & 300 & $100 \%$ \\
\hline Sometimes & 0 & $0 \%$ \\
\hline No, never & 0 & $0 \%$ \\
\hline N & 300 & $100 \%$ \\
\hline
\end{tabular}

15. How would you evaluate the communication between you, the Doctor and Nurse?

\begin{tabular}{|l|l|l|}
\hline Answer & $\mathrm{n}$ & $\%$ \\
\hline Very good & 100 & $33.3 \%$ \\
\hline Good & 180 & $60 \%$ \\
\hline With problems & 20 & $6.6 \%$ \\
\hline Bad & 0 & 0 \\
\hline N & 300 & $100 \%$ \\
\hline
\end{tabular}


16. Are the cleanliness and equipment in ambulance and waiting areas important when evaluating your satisfaction?

\begin{tabular}{|l|l|l|}
\hline Answer & $\mathrm{n}$ & $\%$ \\
\hline Yes, definitely & 270 & $90 \%$ \\
\hline I do not know & 30 & $10 \%$ \\
\hline No & 0 & $0 \%$ \\
\hline N & 300 & $100 \%$ \\
\hline
\end{tabular}

17. Is the neatness of Nurses and Doctors in the ambulance important when you assess your satisfaction?

\begin{tabular}{|l|l|l|}
\hline Answer & $\mathrm{n}$ & $\%$ \\
\hline Yes, definitely & 240 & $80 \%$ \\
\hline I do not know & 40 & $13.3 \%$ \\
\hline Not at all & 20 & $6.6 \%$ \\
\hline N & 300 & $100 \%$ \\
\hline
\end{tabular}

18. Are areas of waiting room and ambulance of your doctor adapted for wheelchair access?

\begin{tabular}{|l|l|l|}
\hline Answer & $\mathrm{n}$ & $\%$ \\
\hline Yes & 100 & $33.3 \%$ \\
\hline Partially & 50 & $16.6 \%$ \\
\hline I do not know & 140 & $46.6 \%$ \\
\hline No & 10 & $3.3 \%$ \\
\hline N & 300 & $100 \%$ \\
\hline
\end{tabular}

19. Are you satisfied with the length of office hours of your doctor?

\begin{tabular}{|l|l|l|}
\hline Answer & $\mathrm{n}$ & $\%$ \\
\hline Yes & 210 & $70 \%$ \\
\hline $\begin{array}{l}\text { I do not know, I do not } \\
\text { care }\end{array}$ & 80 & $26.6 \%$ \\
\hline No, I am not & 10 & $3.3 \%$ \\
\hline N & 300 & $100 \%$ \\
\hline
\end{tabular}

20. Do you use the option of ordering at a specific time for a fee?

\begin{tabular}{|l|l|l|}
\hline Answer & $\mathrm{n}$ & $\%$ \\
\hline Yes & 20 & $6.6 \%$ \\
\hline No & 210 & $70 \%$ \\
\hline $\begin{array}{l}\text { I do not know about this } \\
\text { option }\end{array}$ & 70 & $23.3 \%$ \\
\hline N & 300 & $100 \%$ \\
\hline
\end{tabular}

21. Have you ever thought about changing your GP?

\begin{tabular}{|l|l|l|}
\hline Answer & $\mathrm{n}$ & $\%$ \\
\hline Yes I thought about it & 20 & $6.6 \%$ \\
\hline I have not thought about it & 40 & $13.3 \%$ \\
\hline $\begin{array}{l}\text { I am satisfied with my } \\
\text { doctor }\end{array}$ & 240 & $80 \%$ \\
\hline $\mathrm{N}$ & 300 & $100 \%$ \\
\hline
\end{tabular}

22. What would be the reasons that might lead to a decision to change your General Practitioner?

\begin{tabular}{|l|c|c|}
\hline Answer & $\mathrm{n}$ & $\%$ \\
\hline $\begin{array}{l}\text { Doubts about the expertise of } \\
\text { the doctor }\end{array}$ & 110 & $36.6 \%$ \\
\hline $\begin{array}{l}\text { Dissatisfaction with medical } \\
\text { approach }\end{array}$ & 140 & $46.6 \%$ \\
\hline $\begin{array}{l}\text { Failure to provide sufficient } \\
\text { information }\end{array}$ & 50 & $16.6 \%$ \\
\hline $\begin{array}{l}\text { Doubts about the expertise of } \\
\text { nurse }\end{array}$ & 0 & $0 \%$ \\
\hline $\begin{array}{l}\text { Dissatisfaction with the } \\
\text { approach of nurse }\end{array}$ & 0 & $0 \%$ \\
\hline $\begin{array}{l}\text { Unsuitable environment of } \\
\text { ambulance \& waiting areas }\end{array}$ & 0 & $0 \%$ \\
\hline Alternatively, indicate the other & 0 & $0 \%$ \\
\hline $\mathrm{N}$ & 300 & $100 \%$ \\
\hline
\end{tabular}




\section{Evaluation of working hypotheses}

Based on analysis of data collected from respondents, we came to the following conclusions:

H1 We assume that for respondents, in evaluation of satisfaction of care by their GP not only medical expertise but also approaches by Doctors and Nurses to patients and communication with them is important.

Hypothesis 1 was confirmed. For 53\% of respondents for evaluating satisfaction in medical expertise is important and for $43 \%$ of respondents a human approach of physician to the patient. The ratio between expertise and approach is essentially balanced. This hypothesis was verified at the beginning of questionnaire and at the end in the last questions where we came to the same results with small variations. Regarding communication with health professionals, respondents evaluated it $60 \%$ as good and as very good perceived by only $33.3 \%$ of respondents. The reasons which lead respondents to this evaluation could be the subject of further research.

$\mathbf{H} 2$ We assume that respondents will not be satisfied with providing of information about their state of health, examinations and treatment.

Hypothesis 2 has not been confirmed. $90 \%$ of respondents said that their Doctor had sufficiently informed them about all aspects of examinations and treatment, and for $83.3 \%$ of the respondents, this information was sufficiently clear. Even $70 \%$ of respondents in the questionnaire said that the doctor allowed them to express agreement or disagreement with the prescribed examinations and treatment. For information on adverse reactions to prescribed medications and supplementary payment, $66.6 \%$ of respondents said that they were always informed and $33.3 \%$ of respondents sometimes. $80 \%$ of respondents said that before the intervention the Nurse explained to them what is going to happen and $20 \%$ of respondents said they were instructed only sometimes.

H3 We assume that respondents will have enough information about the possibilities of preventive examinations and vaccinations, from GP and also from other sources, and that they follow preventive examinations.

Hypothesis 3 has not been confirmed. As regards the information provided by Doctors, they are sufficient for $63.3 \%$ of respondents. It is interesting that this is only in respondents in the age group 40-60 years $(33.3 \%)$ and $60-80$ years (30\%). 6.6\% of respondents aged 20-40 years said they were partly informed by the Doctor and $30 \%$ of respondents said they have more information from other sources. These respondents are in the age groups 20-40 and 40-60 years. This information about awareness cannot be evaluated according to age because we do not have the same number of respondents in all age groups. On the question of information from other sources, 13 respondents and $20 \%$ of them answered that they have much information from television and radio, 10\% received information from the family and the same proportion of $6.6 \%$ were provided with this information from the internet and magazines. The worse situation among respondents is regarding preventive examinations because $50 \%$ do not attend them, 36.6\% irregularly and only $13.3 \%$ regularly. These results are not affected by the age of respondents, as there is small representation of younger respondents between them for which these preventive examinations are of utmost importance.

H4 We expect that the majority of respondents would not change their GP because they are in his care for a long time 
and are satisfied with his care, availability and tactful approach.

Hypothesis 4 was confirmed. Overall satisfaction with the care of their General Practitioner was expressed by $80 \%$ of surveyed respondents and 80\% expressed their satisfaction with it in Question 21 about the change of Practitioner. 100\% of respondents also reflected satisfaction with the approach of Nurses and Doctors regarding examinations and confidential communication. The length of office hours suits $70 \%$ of respondents.

H5 We assume that for the satisfaction rating a clean and neat environment of ambulance and waiting areas as well as equipment are very important.

Hypothesis 5 was confirmed. When evaluating satisfaction for $90 \%$ of respondents, cleanliness of ambulance facilities and waiting room was of importance for them. Even the neatness of Nurses and Doctors is important to $80 \%$ of respondents. Only $33.3 \%$ of respondents expressed satisfaction with disabled access into ambulances, $16.6 \%$ reported partial access and $46.6 \%$ could not assess whether the ambulance and waiting room areas allow it. Only 3.3\% replied that they are not facilitated for it.

\section{Recommendations for Practice}

Based on the information we have acquired in our research we can conclude that the public is satisfied with the care of Practitioners. The results showed that our Doctors and Nurses should improve their communicating with patients. In the future, more of these problems could be addressed in other research which would be focused on communication with patients. In our study we have actually not identified what mistakes our medics are doing.

Pleasing is the finding of sufficient informing of our public about performances and treatment and it is certainly necessary to pay attention to it in the future because ignorance may cause mistrust of public to Health Care Workers.

I would be more appealing for our Doctors, and also Nurses, closer adherence to preventive examinations, particularly among young people, because now diseases are so widespread in civilization which are in time detected, monitored and treated to have a greater percentage of successful treatment.

There should be a place for even better communication with patients and also decoration of waiting room with posters and reading. To improve access for people with disabilities for care by a General Practitioner, improvement of those areas and waiting rooms is necessary. In conclusion it should be stressed that an empathetic approach, helpfulness, good communication, sufficient awareness and, of course, certainly the expertise of Doctors and Nurses, are judgmental factors of satisfaction with the care our society provides in primary care through the Outpatient Practitioners. Despite financial shortages in our health, we also must think about the technical equipment of clinics to provide care on a certain professional level, but also to increase patient comfort while in the waiting room and during examinations.

\section{References}

1. HANZLIKOVA A, et al. (2004) Сотmunity Nursing. Martin, Osveta, 279 p. ISBN 80-8063-155-7. 